\title{
Total antioxidant capacity, total phenolic content and mineral elements in the fruit peel of Myrciaria cauliflora
}

\author{
Capacidade antioxidante total, conteúdo fenólico total e \\ elementos minerais nas cascas do fruto de Myrciaria cauliflora
}

\section{Autores | Authors}

凶 Clináscia Rodrigues Rocha

ARAÚJO

Universidade Federal de Minas Gerais (UFMG)

Departamento de Química Av. Antônio Carlos, 6627- Pampulha CEP 31270-901

Belo Horizonte/MG - Brazil e-mail:clinascia@ufmg.br

Thiago de Mello SILVA

Universidade Federal de Minas Gerais (UFMG)

Departamento de Química

Belo Horizonte/MG - Brazil e-mail: silvatm@ufmg.br

\section{Monica LOPES}

Paula VILLELA

Universidade Federal dos Vales do Jequitinhonha e Mucurí (UFVJM)

Departamento de Química

Diamantina/MG - Brazil

e-mail:monicalopes_m@hotmail.com paulavillela88@hotmail.com

\section{Antônio Flávio de Carvalho} ALCÂNTARA

Universidade Federal de Minas Gerais (UFMG)

Departamento de Química Belo Horizonte/MG - Brazil e-mail: aalcantara@zeus.qui.ufmg.br

Nísia Andrade Villela DESSIMONI-PINTO

Universidade Federal dos Vales do Jequitinhonha e Mucurí (UFVJM)

Departamento de Química Diamantina/MG - Brazil e-mail: nisiavillela@yahoo.com.br

$\triangle$ Autor Correspondente / Corresponding Author

Recebido / Received: 05/27/2013 Aprovado / Approved: 11/06/2013 Publicado / Published: dez./2013

\section{Summary}

The in vitro antioxidant capacity, total phenolic content and mineral elements of the fruit peel of Myrciaria cauliflora were investigated. The antioxidant capacity was analyzed by the diphenylpicrylhydrazyl (DPPH), 2,2'-azino-bis(3ethylbenzthiazoline-6-sulfonic acid) (ABTS), ferric reducing antioxidant power (FRAP) and $\beta$-carotene methods. The assays based on the DPPH $\left(\mathrm{EC}_{50}=3.18 \mathrm{~g}\right.$ sample/g DPPH), ABTS ${ }^{\bullet+}\left(1017 \mu \mathrm{mol}\right.$ Trolox/g sample), FRAP (1676 $\mu \mathrm{M} \mathrm{Fe}_{2} \mathrm{SO}_{4} / \mathrm{g}$ sample) and $\beta$-carotene/linoleic acid (70\% of oxidation inhibition) methods indicated a high antioxidant capacity of the fruit peel extract of the plant. The Folin-Denis method was more efficient in determining the total phenolic compound contents in the different solvents than the Folin-Ciocalteu one. Extractions made with 4:1 methanol-water, 4:1 ethanol-water, 3:2 ethanol-water and 3:2 acetonewater solutions using the Folin-Denis method exhibited high contents of phenolic compounds (18.95, 14.06, 12.93 and $11.99 \mathrm{mg} \mathrm{GAE} / \mathrm{g}$, respectively). Potassium was the major element found in the fruit peel, followed by phosphorus, calcium, magnesium and iron, in that order. As a result, the fruit peel of $M$. cauliflora can be considered as an important source of natural antioxidants and essential elements of easy access for the population and for application in the food industry.

Key words: Antioxidant capacity; Folin-Denis; Folin Ciocalteu; mineral elements.

\section{Resumo}

A capacidade antioxidante, o conteúdo fenólico total e os elementos minerais foram investigados, in vitro, nas cascas dos frutos de Myrciaria cauliflora. A capacidade antioxidante foi analisada pelos métodos difenilpicrilhidrazina (DPPH), [2,2'-azino-bis(3-etilbenzotiazolin)-6-sulfônico] (ABTS), poder redutor do íon férrico (FRAP) e $\beta$-caroteno. Os ensaios baseados nos métodos DPPH $\left(\mathrm{EC}_{50}=3,18 \mathrm{~g}\right.$ amostra/g DPPH), ABTS*+ (1017 $\mu \mathrm{mol}$ Trolox/g amostra), FRAP (1676 $\mu \mathrm{M} \mathrm{Fe} \mathrm{SO}_{4} / \mathrm{g}$ amostra) e $\beta$-carotene/ácido linoleico (70\% de inibição da oxidação) indicam alta capacidade antioxidante dos extratos das cascas dos frutos dessa planta. O método Folin-Denis foi mais eficiente quando comparado com FolinCiocalteu para a determinação de compostos fenólicos em diferentes solventes. Extrações com soluções de 4:1 metanol-água, 4:1 etanol-água, 3:2 etanol-água e 3:2 acetona-água, usando o método Folin-Denis, exibem alto conteúdo de compostos fenólicos (18,95; 14,06; 12,93; 11,99 mg GAE/g, respectivamente). Potássio é o elemento encontrado em maior proporção nas cascas deste fruto, seguido pelo fósforo, cálcio, magnésio e ferro. Como resultado, cascas do fruto de $M$. cauliflora podem ser consideradas uma importante fonte de antioxidantes naturais e elementos essenciais de fácil acesso à população e aplicação pela indústria de alimentos.

Palavras-chave: Capacidade antioxidante; Folin-Denis; Folin Ciocalteu; elementos minerais. 


\section{Introduction}

Free radicals are produced during oxidative metabolism in living organisms (RAHMAN and ADCOCK, 2006) or under stress conditions, such as changes in temperature, exposure to UV radiation and attacks by pathogens (DIXON and PAIVA, 1995). The protective mechanism is capable of intercepting or stopping the chain reactions which are typical of free radicals, converting them into less harmful molecules. As a result, antioxidants efficiently repair oxidative damage in cells (DU et al., 2009). Natural antioxidants exhibit protective effects against free radicals. The antioxidant properties of plant foods have been attributed to their terpenoid, carotenoid and phenolic constituents (PÉREZ-JIMÉNEZ et al., 2008). Phenolic compounds are employed in the treatment of cardiovascular diseases (JOSHIPURA et al., 2001; NACZK and SHAHIDI, 2006) and their antioxidant properties have been extensively investigated over the last few years (ABREU et al., 2008; CHOUDHARY et al., 2009; MORAIS et al., 2010; HOSSAIN and RAHMAN, 2011). The high concentration of phenolic compounds in fruit peels and seeds provides an appropriate justification for the use of fruit byproducts as a source of natural antioxidants (FRANCISCO and RESURRECCION, 2009).

Myrciaria cauliflora (Myrtaceae) is popularly known in Brazil as "jabuticabeira-preta", "jabuticabeira-ponhema" or "jabuticabeira-açu". This plant is widely used in the treatment of hemoptysis, asthma, diarrhoea and chronic inflammation of the tonsils (REYNERTSON et al., 2006). The mature fruit is red to blackish purple and exhibits low acidity and a sweet flavour (REYNERTSON et al., 2008), being often eaten fresh or processed as jams, juice and liqueurs. Deterioration of the fruit is observed within two to three days post-harvest, mainly due to pulp fermentation and extreme loss of water. As a consequence, there is a significant amount of natural antioxidants in the peel of the deteriorated fruits of $M$. cauliflora, that could be better explored by the food and pharmaceutical industries.

The leaves of $M$. cauliflora have been studied and indicated the presence of phenolic and tannin constituents. The essential oil contains high concentrations of $\gamma$-eudesnol, germacrene and elemol (DUARTE et al., 2010). The leaf extract exhibited antimicrobial activity against some bacteria such as Streptococcus mitis, S. mutans, S. sanguinis, S. oralis, S. salivarius and Lactobacillus casei (MACEDO-COSTA et al., 2009). Some sugars, organic acids, minerals, lipids and phenolic compounds were also identified in the fruits of the plant (EINBOND et al., 2004; REYNERTSON et al., 2008).

A few studies about the fruit peel of $M$. cauliflora can be found in the literature, describing the total phenolic content, total anthocyanin content and the antioxidant activity, as determined by the Folin-Ciocalteu, differential $\mathrm{pH}$ and $\beta$-carotene methods, respectively
(SANTOS et al., 2010). Ultrasound assisted, agitated bed and soxhlet extractions in ethanol were employed. However, the most trivial extraction process for the general population, i.e. solvent extraction at room temperature, was not considered in any of these studies. Other studies about the fruit peel of $M$. cauliflora at different ripening stages reported the proximate and mineral compositions, flavonoid content and the inhibition of important enzymes for the carbohydrate metabolism (ALEZANDRO et al., 2013b). Moreover, a recently published study suggested that the fruit peel of $M$. cauliflora had lipid-lowering effects (ARAÚJO et al., 2013).

Polar extracts obtained from the fruit peel of $M$. jaboticaba exhibited antiproliferative effects against leukaemia, and the non-polar extracts were active against prostate cancer cells (LEITE-LEGATTI et al., 2012). Beneficial health effects were observed in diabetic rats, improving their lipid profiles and reducing oxidative stress (ALEZANDRO et al., 2013a).

Thus the present work describes a more exhaustive investigation of the total antioxidant capacity, total phenolic content (TPC) and mineral elements of fruit peel extracts of $M$. cauliflora. The choice of the solvent is an important factor in the extraction process of phenolic compounds from plant materials (ZHAO et al., 2006; IKRAM et al., 2009). Therefore the present work also described the use of different solvent mixtures (including water, methanol, ethanol and acetone) in the extraction process of the phenolic compounds. The antioxidant capacity was analyzed by the diphenylpicrylhydrazyl (DPPH), 2,2'-azino-bis(3-ethylbenzthiazoline-6-sulfonic acid) (ABTS), ferric reducing antioxidant power (FRAP) and $\beta$-carotene methods. These methods determine different antioxidant powers such as the capacity to scavenge free radicals (DPPH and ABTS methods) and chelate metal ions (FRAP methods). The $\beta$-carotene method prevents the formation of radicals and improves the endogenous antioxidant system. The total phenolic content was evaluated using the Folin-Ciocalteu and FolinDenis methods. The mineral elements were determined by atomic absorption spectroscopy.

\section{Material and methods}

\subsection{General}

Absorbance measurements to determine the antioxidant activity by the DPPH, ABTS, FRAP and $\beta$-carotene methods, and the quantitative analyses of the total phenolic content by the Folin-Ciocalteu and FolinDenis methods were recorded using a Shimadzu Mini 1240 UV-VIS Spectrophotometer. The mineral elements calcium, copper, iron, magnesium, manganese, potassium and zinc were determined using a Varian SpectrAA 50 
Flame Atomic Absorption Spectrometer. Phosphorus was analyzed using an Analyser 910 Flame Photometer.

\subsection{Chemical reagents}

ABTS, DPPH, ferrous sulphate heptahydrate, Folin-Ciocalteu reagent, Folin-Denis reagent, gallic acid, iron (III) chloride hexahydrate, linoleic acid, potassium persulphate, sodium acetate trihydrate, sodium carbonate, 2,4,6-tris-(2-pyridyl)-s-triazine (TPTZ) and 6-hydroxy2,5,7,8-tetramethylchromane-2-carboxylic acid (Trolox) were purchased from Sigma-Aldrich. Acetone, chloroform, ethanol, glacial acetic acid, hydrochloric acid, methanol, $\beta$-carotene and polyoxyethylene sorbitan monopalmitate (Tween 40) were purchased from Merck. The standard solutions of calcium nitrate, magnesium nitrate, zinc nitrate, iron nitrate, copper nitrate, manganese nitrate, potassium nitrate and phosphate (all with purity > 99\%) were also purchased from Merck.

\subsection{Sample preparation}

Mature fruits were harvested in the City of Diamantina (State of Minas Gerais, Brazil) at a latitude of S $18^{\circ} 14^{\prime} 58^{\prime \prime}$ and longitude of W 43 $36^{\prime}$ 01' in November 2009. The identity of a voucher specimen was checked by a morphological analysis and compared with authentic material deposited in the herbarium of the Instituto de Ciências Biológicas of the Federal University of Minas Gerais, under the code B1987. The newly harvested fresh fruits were washed and sanitized by immersion in a sodium hypochlorite solution $(200 \mathrm{mg} / \mathrm{L})$ for $10 \mathrm{~min}$. The fruit peel and pulps were manually separated. The fruit peel was dried in an oven with forced air circulation for seven days at $40 \pm 5^{\circ} \mathrm{C}$. The dried fruit peel was crushed and sieved (80 mesh).

\subsection{Evaluation of the antioxidant activity}

The dried and powered fruit peel $(1.00 \mathrm{~g})$ was homogenized in $40.0 \mathrm{~mL}$ of $(1: 1)$ methanol-water solution for $1 \mathrm{~h}$ at room temperature. This mixture was centrifuged at 3000 rpm (approximately $500 \mathrm{~g}$-force) for $15 \mathrm{~min}$. The supernatant was collected and denominated Extract 1. The solid residue was submitted to the same homogenization and centrifugation process using $40.0 \mathrm{~mL}$ of $(7: 3)$ acetone-water solution, obtaining Extract 2. The two extracts were combined and the solvents evaporated off. The solid extract was diluted in methanol at different concentrations, providing samples A $(0.50 \mathrm{mg} / \mathrm{mL}), B$ (1.00 mg/mL), C (1.50 mg/mL) and D (2.00 mg/mL). All experiments were carried out in triplicate.

The DPPH free radical scavenging activity was determined based on the method previously described in the literature (BRAND-WILLIAMS et al., 1995; SÁNCHEZMORENO et al., 1998). Aliquots of the samples A-D (0.10
$\mathrm{mL}$ ) were added to $3.90 \mathrm{~mL}$ of the $0.06 \mathrm{mM}$ DPPH solution in the absence of light, and the mixture vigorously shaken and then incubated for $30 \mathrm{~min}$ at $37^{\circ} \mathrm{C}$. The absorbance data were registered at $515 \mathrm{~nm}$. An antioxidant capacity was evaluated by a $50 \%$ concentration $\left(\mathrm{EC}_{50}\right.$ ) of free radicals in relation to the initial concentration of free radicals in the $\mathrm{DPPH}$ solution.

The ABTS $^{\bullet+}$ free radical scavenging activity was determined based on the method previously described in the literature (ARNAO et al., 2001). The ABTS •+ radical cation was generated from $5.00 \mathrm{~mL}$ stock solution of ABTS containing $88.0 \mu \mathrm{L}$ of a potassium persulphate solution. The ABTS solution was maintained in the absence of light for $16 \mathrm{~h}$ at room temperature, and $1.00 \mathrm{~mL}$ then diluted with ethanol to obtain an absorbance of 0.70 at $734 \mathrm{~nm}$. Samples A-D $(0.03 \mathrm{~mL})$ were transferred to test tubes containing $3.00 \mathrm{~mL}$ of the $\mathrm{ABTS}^{\bullet+}$ radical solution and homogenized. The absorbance was registered after $6 \mathrm{~min}$, and the scavenging activity on the $\mathrm{ABTS}^{\bullet+}$ free radical was compared with a standard Trolox solution (1000 mM), which is a potent antioxidant.

The FRAP determination was based on a method previously described in the literature (FIRUZI et al., 2005). A FRAP solution was prepared by the addition of $25.0 \mathrm{~mL}$ of acetate buffer (300 mM) to $2.50 \mathrm{~mL}$ of ferric chloride hexahydrate $(20 \mathrm{mM})$ and $2.50 \mathrm{~mL}$ of TPTZ (10 $\mathrm{mM})$. Samples A-D (0.09 mL) were added to $0.27 \mathrm{~mL}$ of distilled water and $2.70 \mathrm{~mL}$ of FRAP reagent. After 30 min of incubation at $37{ }^{\circ} \mathrm{C}$, the absorbance data were registered at $595 \mathrm{~nm}$. The antioxidant capacity of the fruit peel extracts was determined from the calibration curve plotted using $\mathrm{FeSO}_{4} \cdot 7 \mathrm{H}_{2} \mathrm{O}$ at concentrations between 500 and $2000 \mathrm{mM}$ as the reference standard.

The test for the inhibition of the oxidation of $\beta$-carotene by peroxide radicals was based on the method previously described in the literature (VELIOGLU et al., 1998). An aliquot $(0.15 \mathrm{~mL})$ of $\beta$-carotene solution in chloroform $(20 \mathrm{mg} / \mathrm{mL})$ was added to a mixture of linoleic acid $(0.12 \mathrm{~mL})$ and Tween $40(1.63 \mathrm{~mL})$. The chloroform was removed by evaporation for $2 \mathrm{~h}$ at $40{ }^{\circ} \mathrm{C}$. The absorbance data for this mixture were registered at 470 $\mathrm{nm}$ and considered as the reference standard. The results were expressed as oxidation inhibition percentages (Ol\%; as shown in Equation 1), considering the decrease in absorbance of the samples A-D $(0.4 \mathrm{~mL})$, where $\mathrm{SA}_{0}$ and $\mathrm{SA}_{120}$ are the values for the absorbance of the test sample at zero time and $120 \mathrm{~min}$, respectively, and $\mathrm{RA}_{0}$ and $\mathrm{RA}_{120}$ are the values for the absorbance of the reference standard at zero time and $120 \mathrm{~min}$, respectively. Trolox $(2.00 \mathrm{mg} / \mathrm{mL}$ in methanol) was used in the tests for the inhibition of the oxidation of $\beta$-carotene for comparison with the results obtained with the fruit peel of $M$. cauliflora (RUFINO et al., 2010).

Antioxidant capacity $(\%)=100-\left[\left(S A_{120}-S A_{0}\right) \times 100 /\left(R A_{120}-R A_{0}\right)\right]$ 
Total antioxidant capacity, total phenolic content and mineral elements in the fruit peel of Myrciaria cauliflora Araújo, C. R. R. et al.

\subsection{Determination of the total phenolic content}

The total phenolic content (TPC) was determined by spectrophotometry as previously described in the literature (ZIELINSKI and KOZLOWSKA, 2000). Acetone, acetone-water (4:1), acetone-water (3:2), ethanol, ethanolwater (4:1), ethanol-water (3:2), methanol, methanol-water $(4: 1)$, methanol-water $(3: 2)$ and water were used as the solvents to extract the TPC. Samples of dried and powered fruit peel $(1.00 \mathrm{~g})$ were submitted to extraction with each of the eluents described above $(25.0 \mathrm{~mL})$, shaking for $4 \mathrm{~h}$ and then centrifuging for 5 min at $1400 \mathrm{rpm}$ (approximately $110 \mathrm{~g}$-force). Each extract was filtered, and aliquots of the resultant solution ( $1.00 \mathrm{~mL}$ each) added to $9.00 \mathrm{~mL}$ of water and $1.00 \mathrm{~mL}$ of Folin-Ciocalteu or Folin-Denis reagent. After $5 \mathrm{~min}, 10.0 \mathrm{~mL}$ of a $7 \%$ sodium carbonate solution were added. The mixture was diluted to 25.0 $\mathrm{mL}$ with water and homogenized. After $60 \mathrm{~min}$, the absorbance data were registered at $725 \mathrm{~nm}$. The TPC was measured using a gallic acid standard and expressed as $\mathrm{mg}$ of gallic acid/g (GAE/g). All the experiments were carried out in triplicate.

\subsection{Mineral analyses}

The concentrations of the mineral elements $\mathrm{Ca}$, $\mathrm{Cu}, \mathrm{Fe}, \mathrm{K}, \mathrm{Mg}, \mathrm{Mn}$ and $\mathrm{Zn}$ were determined by flame atomic absorption spectroscopic analysis as previously described in the literature (NANDA et al., 2003). The phosphorus concentration was determined by spectrophotometry as described by Rowell (1994), and the absorbance of the samples was measured at $725 \mathrm{~nm}$. Samples of dried and powered fruit peel $(0.20 \mathrm{~g})$ were incinerated in a muffle furnace at $550{ }^{\circ} \mathrm{C}$ to complete oxidation of all carbonaceous material. The ash was cooled to room temperature, dissolved in $10.0 \mathrm{~mL}$ of $\mathrm{HCl}$ $(0.1 \mathrm{~N})$, transferred to a $50.0 \mathrm{~mL}$ volumetric flask and the volume completed with water. All experiments were carried out in triplicate.

\subsection{Statistical analyses}

All data were expressed as the mean \pm standard deviation of triplicate experiments. The statistical analysis was carried out using Statistica 7.0 software (STATSOFT, 2001). Differences were tested for significance using the ANOVA procedure, with a significance level of $p<0.05$.

\section{Results and discussion}

\subsection{Determination of antioxidant activity}

Table 1 shows the antioxidant capacity of the fruit peel of $M$. cauliflora using different analytical methods. The DPPH antioxidant capacity of the fruit peel $\left(\mathrm{EC}_{50}=3.18 \mathrm{~g}\right.$ dried sample/g DPPH, which corresponds to $0.0775 \mathrm{mg}$ dried sample/mL DPPH), was significantly higher than
Table 1. Antioxidant capacity of the fruit peel of $M$. cauliflora using different analytical methods.

\begin{tabular}{cc} 
Method & Antioxidant capacity \\
\hline $\mathrm{DPPH}\left(\mathrm{EC}_{50} \mathrm{~g} / \mathrm{g} \mathrm{DPPH}\right)$ & $3.18 \pm 0.01$ \\
$\mathrm{ABTS} \cdot+(\mu \mathrm{mol} \mathrm{Trolox} / \mathrm{g})$ & $1017.80 \pm 0.04$ \\
$\mathrm{FRAP}\left(\mu \mathrm{mol} \mathrm{Fe}_{2} \mathrm{SO}_{4} / \mathrm{g}\right)$ & $1676.80 \pm 0.02$ \\
\hline
\end{tabular}

the corresponding value for the fruit extracts (pulp and peel, without seeds), $\mathrm{EC}_{50}=138.0 \mathrm{~g}$ dried sample $/ \mathrm{g} \mathrm{DPPH}$ (RUFINO et al., 2010), considering that lower $\mathrm{EC}_{50}$ values correspond to higher antioxidant activities (YEH et al., 2011). Moreover, the antioxidant capacity of the fruit peel of M. cauliflora as measured by the DPPH radical capture method was significantly higher than that of other plant species, such as the peels of Citrus paradise, $C$. sinensis, C. limon and $C$. aurantiifolia $\left(\mathrm{EC}_{50}=5.15,4.99\right.$, 3.77 and $1.72 \mathrm{mg}$ dried sample/mL DPPH, respectively) (GUIMARÃES et al., 2010) and the fruit extracts of Ficus glomerata (9.04 g of crude extract/g DPPH) (VERMA et al., 2010).

A similar mechanism used to analyze the antioxidant capacity is based on the capture of the ABTS ${ }^{\bullet+}$ radical, and higher values of mol Trolox/g also correspond to higher antioxidant capacities. Table 1 shows the antioxidant capacity of the fruit peel extract as measured using the ABTS method. The test gave a value of $1017.80 \mu \mathrm{mol}$ Trolox/g for the fruit peel of the plant, a result significantly higher than the value found for the fruit extract $(317.0 \mu \mathrm{mol}$ Trolox/g) (RUFINO et al., 2010). The antioxidant activity of the fruit peel of $M$. cauliflora as evaluated by the ABTS method was more expressive in relation to the fruits of other plant species with recognized antioxidant activity, such as Malpighia emarginata (953 $\mu \mathrm{mol} / \mathrm{g})$, Euterpe edulis (606.0 $\mu \mathrm{mol} / \mathrm{g})$, Byrsonima dealbata $(412 \mu \mathrm{mol} / \mathrm{g})$, Mouriri pusa (346 $\mu \mathrm{mol} / \mathrm{g})$, Eugenia pyriformis (182.0 $\mu \mathrm{mol} / \mathrm{g}$ ), Blepharocalyx salicifolius (166.0 $\mu \mathrm{mol} / \mathrm{g}$ ), Mouriri

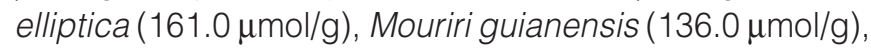
Syzygium cumini (125.0 $\mu \mathrm{mol} / \mathrm{g})$, Anacardium occidentale (79.4 $\mu \mathrm{mol} / \mathrm{g})$, Spondias tuberosa $(77.0 \mu \mathrm{mol} / \mathrm{g})$, Hancornia speciosa $(65.6 \mu \mathrm{mol} / \mathrm{g})$, Euterpe oleracea $(64.5 \mu \mathrm{mol} / \mathrm{g})$, Spondias mombin $(40.7 \mu \mathrm{mol} / \mathrm{g})$, Platonia insignis (18.1 $\mu \mathrm{mol} / \mathrm{g}$ ) and Copernicia prunifera (16.4 $\mu \mathrm{mol} / \mathrm{g})$. However, this antioxidant capacity was lower than the value found for Myrciaria dubia (1237 $\mu \mathrm{mol} / \mathrm{g}$ ) (RUFINO et al., 2010). The DPPH and ABTS tests indicated that the fruit peel of $M$. cauliflora acts as a free radical scavenger, preventing the propagation of its chain reactions.

The antioxidant activity of the fruit peel of M. cauliflora as measured by the FRAP method (1676.80 $\mu \mathrm{mol} \mathrm{Fe}_{2} \mathrm{SO}_{4} / \mathrm{g}$ ), see Table 1, was higher than the corresponding activity observed for the fruit (pulp and peel) extract of the plant $\left(635 \mu \mathrm{mol} \mathrm{Fe}_{2} \mathrm{SO}_{4} / \mathrm{g}\right)$ 
Total antioxidant capacity, total phenolic content and mineral elements in the fruit peel of Myrciaria cauliflora Araújo, C. R. R. et al.

(RUFINO et al., 2010). Moreover, its antioxidant capacity was higher than the values obtained for other fruits with recognized antioxidant ability (Pérez-Jimenes et al., 2008), such as Blepharocalyx salicifolius, Mouriri guianensis, Syzygium cumini, Hancornia speciosa, Spondias mombin, and Copernicia prunifera (299, 274, 173, 163 and 18.8 $\mu \mathrm{mol} \mathrm{Fe} \mathrm{SO}_{4} \cdot \mathrm{g}^{-1}$, respectively) (RUFINO et al., 2010). The FRAP antioxidant test indicates that the fruit peel of $M$. cauliflora acts as a reducing agent by donating a hydrogen atom to the ferric complex, inhibiting the radical chain reactions.

Table 2 shows the antioxidant capacity of the fruit peel of $M$. cauliflora based on the oxidation inhibition percentage with different $\beta$-carotene concentrations. The increase in the $\beta$-carotene concentration (to $0.5,1.0,1.5$ and $\left.2.0 \mathrm{mg} \cdot \mathrm{mL}^{-1}\right)$ was related to the oxidation inhibition percentage $(\mathrm{Ol} \%)$ of the samples $(\mathrm{Ol} \%=72.1,75.9,82.5$ and 87.5 , respectively). The antioxidant activity of the fruit peel extract at $2.0 \mathrm{mg} \cdot \mathrm{mL}^{-1}(\mathrm{Ol} \%=87.5 \%)$ was similar to value obtained with Trolox at the same concentration $(\mathrm{O} \%=89.5 \%)$, confirming the powerful antioxidant capacity of this plant material. In fact, the antioxidant capacity of the fruit peel of $M$. cauliflora was higher than the corresponding capacity of fruits of Punica granatum at $0.2 \mathrm{mg} / \mathrm{mL}(\mathrm{OI} \%=76.6)$ (ÇAM and $\mathrm{HISIL}, 2010)$ and the fruit extract of Ficus glomerata $(\mathrm{Ol} \%=49.75)$ (VERMA et al., 2010).

The mechanism of bleaching $\beta$-carotene is mediated by hydroperoxide free radicals, which are formed from the abstraction of hydrogen atoms from the diallylic methylene groups of linoleic acid. The linoleic acid free radicals attack the highly unsaturated system of the $\beta$-carotene. As a result, the $\beta$-carotene molecules undergo rapid discoloration in the absence of an antioxidant (JAYAPRAKASHA et al., 2007). In the present study, the fruit peel extracts of $M$. cauliflora prevented the $\beta$-carotene bleaching by neutralizing the linoleate-free radical and other free radicals formed in the test mixture.

\subsection{Determination of the total phenolic content}

Table 3 shows the total phenolic content found in the extracts of the fruit peel of $M$. cauliflora using the FolinDenis and Folin-Ciocalteau methods with different solvent mixtures. The extraction of the phenolic compounds was more efficient using the Folin-Denis method than using the Folin-Ciocalteau one. In fact, the total phenolic content as measured by the Folin-Ciocalteau method gave low values (1.35 mg GAE/g for acetone and $4.43 \mathrm{mg} \mathrm{GAE} / \mathrm{g}$ for $4: 1$ ethanol-water solution), and the use of different solvent mixtures did not promote significant statistical variations in the total phenolic contents of the fruit peel extracts of M. cauliflora.

On the other hand, the total phenolic content as measured by the Folin-Denis method promoted significant
Table 2. Antioxidant activity as determined by $\beta$-carotene bleaching for the fruit peel of $M$. cauliflora.

\begin{tabular}{|cc} 
Concentration & $\begin{array}{c}\text { Antioxidant capacity } \\
\text { (\% of Oxidation inhibition) }\end{array}$ \\
\hline$\beta$-carotene at $0.5 \mathrm{mg} / \mathrm{mL}$ & $72.10 \pm 0.06$ \\
$\beta$-carotene at $1.0 \mathrm{mg} / \mathrm{mL}$ & $75.90 \pm 0.11$ \\
$\beta$-carotene at $1.5 \mathrm{mg} / \mathrm{mL}$ & $82.70 \pm 0.32$ \\
$\beta$-carotene at $2.0 \mathrm{mg} / \mathrm{mL}$ & $87.50 \pm 0.12$ \\
Trolox $2.0 \mathrm{mg} / \mathrm{mL}$ & $89.50 \pm 0.23$ \\
\hline
\end{tabular}

Table 3. Total phenolic content (mg GAE/g) in the fruit peel of $M$. cauliflora extracted using different solvent mixtures and methods (Folin-Denis and Folin-Ciocalteu).

\begin{tabular}{lcc}
\multicolumn{1}{c}{ Solvent mixture } & Folin-Denis & Folin-Ciocalteu \\
Water & $10.81^{\mathrm{bc}} \pm 0.17$ & $2.74^{\mathrm{a}} \pm 1.18$ \\
Methanol & $4.02^{\mathrm{cd}} \pm 0.08$ & $3.11^{\mathrm{a} \pm} 2.52$ \\
4:1 Methanol-water & $18.95^{\mathrm{a}} \pm 0.36$ & $4.14^{\mathrm{a}} \pm 0.37$ \\
3:2 Methanol-water & $10.83^{\mathrm{bc}} \pm 0.21$ & $2.51^{\mathrm{a} \pm} 0.60$ \\
Ethanol & $9.23^{\mathrm{bcd}} \pm 0.12$ & $2.42^{\mathrm{a}} \pm 0.60$ \\
4:1 Ethanol-water & $14.06^{\mathrm{ab}} \pm 0.46$ & $4.43^{\mathrm{a}} \pm 0.67$ \\
3:2 Ethanol-water & $12.93^{\mathrm{ab}} \pm 0.70$ & $3.48^{\mathrm{a}} \pm 1.59$ \\
Acetone & $1.56^{\mathrm{d}} \pm 0.21$ & $1.35^{\mathrm{a}} \pm 0.21$ \\
4:1 Acetone-water & $8.80^{\mathrm{bcd}} \pm 1.04$ & $4.03^{\mathrm{a}} \pm 0.39$ \\
3:2 Acetone-water & $11.99^{\mathrm{abc}} \pm 0.21$ & $3.05^{\mathrm{a}} \pm 0.31$
\end{tabular}

Values expressed as the means \pm standard deviation. Means followed by at least one different superscript lowercase letter within a same column are significantly different $(p<0.05)$ by the one way-ANOVA.

statistical variations when different solvent mixtures were employed. The most efficient solvent mixtures were the 4:1 methanol-water, 4:1 ethanol-water, 3:2 ethanol-water and 3:2 acetone-water solutions, exhibiting the highest TPC values (18.95, 14.06, 12.93 and $11.99 \mathrm{mg} \mathrm{GAE} / \mathrm{g}$, respectively). However, pure acetone and methanol were the least efficient solvents for the extraction of phenolic compounds by the Folin-Denis method (1.56 and $4.02 \mathrm{mg}$ $\mathrm{GAE} / g$, respectively).

The TPC values obtained for the fruit peel of M. cauliflora were similar to the corresponding values obtained with the fruit peels of Hymenaea courbaril and Callocarpum mamosum (17.12 and $14.88 \mathrm{mg}$ GAE/g, respectively). In addition, these TPC values were significantly higher than the corresponding values reported for the fruit peels of Passiflora tarminiana, Elaeis oleifera (American oil palm), Theobroma grandiflorum, Passiflora mollissima, Passiflora quadrangularis, Bactris gasipaes, Poroqueiba sericea, Sicana odorifera, Macadamia integrifolia, Solanum sessiliflorum, Solanum quitoense and Borojoa patinoi (2.88, 2.82, 2.52, 2.46, $1.20,1.08,1.07,0.969,0.937,0.874,0.836$ and $0.615 \mathrm{mg}$ GAE/g, respectively) (CONTRERAS-CALDERÓN et al., 2011). The high TPC value obtained for M. cauliflora may be responsible for its high antioxidant capacity 
Total antioxidant capacity, total phenolic content and mineral elements in the fruit peel of Myrciaria cauliflora Araújo, C. R. R. et al.

(BAHRAMIKIA et al., 2009; SAHREEN et al., 2010; BARROS et al., 2012).

The TPC values found in the present work were low (553.6 mg GAE/ g) when compared to a previous study with Myrciaria jaboticaba peels (LEITE-LEGATTI et al., 2012). In that study, fresh fruits were employed, providing higher TPC values than the corresponding values obtained for the TPC of the dried fruit. The high TPC values registered in these studies may be an indication of the antioxidant activity of the plants (SILVA et al., 2012).

\subsection{Analyses of the mineral elements}

The concentration of mineral elements in the fruit peel of $M$. cauliflora is shown in Table 4. Potassium was the most abundant mineral in the fruit peel $(1.060 \mathrm{mg} / \mathrm{g}$ of sample). This mineral is an essential dietary nutrient and fundamental to the regulation of the acid-base and water balances (SULAIMAN et al., 2011). The minerals phosphorus and calcium were also abundant ( 0.377 and $0.113 \mathrm{mg} / \mathrm{g}$ of sample, respectively). Other minerals were detected at low concentrations, such as $\mathrm{Mg}, \mathrm{Fe}, \mathrm{Zn}, \mathrm{Cu}$ and $\mathrm{Mn}(0.065,0.032,0.026,0.014$ and $0.009 \mathrm{mg} / \mathrm{g}$ of sample, respectively). The concentrations of $\mathrm{P}, \mathrm{Mn}, \mathrm{Zn}$, $\mathrm{Fe}$ and $\mathrm{Cu}$ in the fruit peel of $M$. cauliflora were higher as compared to the fruit pulps from this same plant $(0.0200$, $0.0028,0.0019,0.0033$ and $0.0006 \mathrm{mg} / \mathrm{g}$ of sample, respectively) (LETERME et al., 2006).

The minerals $\mathrm{K}, \mathrm{Mg}$, and $\mathrm{Ca}$ were found in higher concentrations in the fruit peel of $M$. cauliflora than in the fruit pulps of Seel lime $(1.012,0.048$, and trace, respectively). Higher values for $\mathrm{Fe}, \mathrm{Mn}, \mathrm{Zn}$ and $\mathrm{Cu}$ were also registered for the fruit peel of $M$. cauliflora when compared to the fruits of other plants. The concentration of Fe in the fruit peels of Lima orante, Sweet lime, Tahiti lime, Pera orange and Ponkan mandarin was 1008.6, 943.4, 768.7, 731.0, and $321.5 \mu \mathrm{g} / 100 \mathrm{~g}$ of sample, respectively (BARROS et al., 2012). The concentration of $\mathrm{Mn}$ in the fruits of Quandong, Finger lime (green) and Finger lime (pink) were $0.0029,0.0045$ and $0.0004 \mathrm{mg} / \mathrm{g}$ of sample, respectively. The concentration of $\mathrm{Zn}$ in the

Table 4. Concentration of mineral elements in the fruit peel of M. cauliflora.

\begin{tabular}{cc}
$\begin{array}{c}\text { Mineral } \\
\text { element }\end{array}$ & $\begin{array}{c}\text { Concentration } \\
\text { (mg/g dry weight of sample) }\end{array}$ \\
$\mathrm{K}$ & $1.060 \pm 0.03$ \\
$\mathrm{P}$ & $0.377 \pm 0.01$ \\
$\mathrm{Ca}$ & $0.113 \pm 0.01$ \\
$\mathrm{Mg}$ & $0.065 \pm 0.01$ \\
$\mathrm{Fe}$ & $0.032 \pm 0.01$ \\
$\mathrm{Zn}$ & $0.026 \pm 0.01$ \\
$\mathrm{Cu}$ & $0.014 \pm 0.01$ \\
$\mathrm{Mn}$ & $0.009 \pm 0.00$ \\
\hline
\end{tabular}

fruits of the Kakadu plum, Davidson's plum, Riberry, Finger lime (green), Finger lime (pink) was 0.0057, 0.0043, $0.0013,0.0085$ and $0.0078 \mathrm{mg} / \mathrm{g}$ of sample, respectively (KONCZAK and ROULLE, 2011). The concentration of $\mathrm{Cu}$ in Brazilian nuts is $11 \mu \mathrm{g} / \mathrm{g}$ of sample (NAOZUKA et al., 2010).

The fruit peel of $M$. cauliflora (100 g) provided $1.13 \%, 5.39 \%, 1.81 \%, 24.85 \%, 27.26 \%$ and $42.44 \%$ of the Dietary Reference Intakes (IOM, 2002) for Ca, P, Mg, $\mathrm{Fe}, \mathrm{Zn}$ and $\mathrm{Mn}$, respectively. Quantities 4.434 and 0.065 $\mathrm{g}$ of fruit peel from the plant were sufficient to provide $100 \%$ of the daily requirements of $\mathrm{K}$ and $\mathrm{Cu}$, respectively (IOM, 2002).

The mineral elements are essential regulators of physiological processes. Calcium, zinc and magnesium are important as cofactors in enzymatic processes, mainly in the structure of the DNA repair system (KONCZAK and ROULLE, 2011). Magnesium is also important in the change of energy in the mitochondria. Iron is essential to the transport of oxygen in the bloodstream. Some minerals are components of important enzymes such as $\mathrm{Mn}, \mathrm{Cu}$ and $\mathrm{Zn}$ for superoxide dismutase and Fe for catalase (EVANS and HALLIWELL, 2001; BARROS et al., 2012). Both these enzymes protect the cell membranes from oxidative damage. The high concentration of these mineral elements in the fruit peel of $M$. cauliflora must promote the formation of these enzymes, and as a consequence provide its antioxidant capacity.

\section{Conclusions}

Several tests can be used to evaluate the antioxidant activity of plant materials, exhibiting different action mechanisms. The fruit peel of $M$. cauliflora showed high antioxidant capacity for the different methods. Moreover, the fruit peel of $M$. cauliflora was a good source of natural antioxidants such as the phenolic compounds, which were better estimated using the Folin-Denis method and 4:1 methanol-water, 4:1 ethanol-water, 3:2 ethanol-water or 3:2 acetone-water solutions as the solvent. The fruit peel of M. cauliflora was also a good source of minerals, potential catalysts of oxidative reactions. As a result, their consumption could contribute with substantial amounts of the dietary reference intakes of these compounds, suggesting their incorporation into the diet for food enrichment.

\section{Acknowledgements}

The authors are grateful to the Conselho Nacional de Desenvolvimento Científico e Tecnológico (CNPq), Fundação Coordenação de Aperfeiçoamento de Pessoal de Nivel Superior (CAPES) and the Fundação de Amparo à Pesquisa do Estado de Minas Gerais (FAPEMIG) for their financial support. 
Total antioxidant capacity, total phenolic content and mineral elements in the fruit peel of Myrciaria cauliflora Araújo, C. R. R. et al.

\section{References}

ABREU, H. A.; LAGO, I. A. S.; SOUZA, G. P.; PILÓ-VELOSO, D.; DUARTE, H. A.; ALCÂNTARA, A. F. C. Antioxidant activity of (+)-bergenin-a phytoconstituent isolated from the bark of Sacoglottis uchi Huber (Humireaceae). Organic \& Biomolecular Chemistry, Cambridge, v. 6, n. 15, p. 2713-2718, 2008. PMid:18633529. http://dx.doi.org/10.1039/b804385j

AlezAndRo, M. R.; GRANATO, D.; GenOVESE, M. I. Jaboticaba (Myrciaria jaboticaba (Vell.) Berg), a Brazilian grapelike fruit, improves plasma lipid profile in streptozotocin-mediated oxidative stress in diabetic rats. Food Research International, Oxford, v. 54, n. 1, p. 650-659, 2013a. http://dx.doi.org/10.1016/j. foodres.2013.07.041

ALEZANDRO, M. R.; DUBÉ, P.; DESJARDINS, Y.; LAJOLO, F. M.; GENOVESE, M. I. Comparative study of chemical and phenolic compositions of two species of jaboticaba: Myrciaria jaboticaba (Vell.) Berg and Myrciaria cauliflora (Mart.) O. Berg. Food Research International, Oxford, v. 54, n. 1, p. 468-477, 2013b. http://dx.doi.org/10.1016/j.foodres.2013.07.018

ARAÚJO, C. R. R.; ESTEVES, E. A.; DESSIMONI-PINTO, N. A. V.; BATISTA, A. G. Myrciaria cauliflora peel flour had a hypolipidemic effect in rats fed a moderately high fat diet. Journal of Medicinal Food, 2013. In press.

ARNAO, M. B.; CANO, A.; ACOSTA, M. The hydrophilic and lipophilic contribution to total antioxidant activity. Food Chemistry, Barking, v. 73, n. 2, p. 239-244, 2001

BAHRAMIKIA, S.; ARDESTANI, A.; YAZDANPARAST, R. Protective effect of four Iranian medicinal plants against free radical-mediated protein oxidation. Food Chemistry, Barking, v. 73, n. 1, p. 37-42, 2009.

BARROS, H. R. M.; FERREIRA, T. A. P. C.; GENOVESE, M. I. Antioxidant capacity and mineral content of pulp and peel from commercial cultivars of citrus from Brazil. Food Chemistry, Barking, v. 134, n. 4, p. 1892-1898, 2012.

BRAND-WILLIAMS, W.; CUVELIER, M. E.; BERSET, C. Use of a free radical method to evaluate antioxidant activity. LTW - Food Science and Technology, Oxford, v. 28, n. 1, p. 25-30, 1995.

ÇAM, M.; HISIL, Y. Pressurised water extraction of polyphenols from pomegranate peels. Food Chemistry, Barking, v. 123, n. 3, p. 878-885, 2010.

CHOUDHARY, M. I.; AZIZUDDIN; JALIL, S.; NAWAZ, S. A.; KHAN, K. M.; TAREEN, R. B.; RAHMAN, A. Antiinflammatory and lipoxygenase inhibitory compounds from Vitex agnus-castus. Phytotherapy Research, Reading, v. 23, n. 9, p. 1336-1339, 2009. PMid:19173281. http://dx.doi.org/10.1002/ptr.2639

CONTRERAS-CALDERÓN, J.; CALDERÓN-JAIMES, L.; GUERRA-HERNÁNDEZ, E.; GARCÍA-VILLANOVA, B. Antioxidant capacity, phenolic content and vitamin $C$ in pulp, peel and seed from 24 exotic fruits from Colombia. Food Research
International, Oxford, v. 44, n. 7, p. 2047-2053, 2011. http:// dx.doi.org/10.1016/j.foodres.2010.11.003

DIXON, R. A.; PAIVA, N. L. Stress-induced phenylpropanoid metabolism. Plant Cell, Kingdom, v. 7, n. 7, p. 1085-1097, 1995.

DU, G.; LI, M.; MA, F.; LIANG, D. Antioxidant capacity and the relationship with polyphenol and vitamin $C$ in Actinidia fruits. Food Chemistry, Barking, v. 113, n. 2, p. 557-562, 2009.

DUARTE, A. R.; SANTOS, S. C.; SERAPHIN, J. C.; FERRI, P. $H$. Environmental influence on phenols and essential oils of Myrciaria cauliflora leaves. Journal of the Brazilian Chemical Society, Campinas, v. 29, n. 9, p. 1672-1680, 2010. http://dx.doi. org/10.1590/S0103-50532010000900011

EINBOND, L. S.; REYNERTSON, K. A.; LUO, X. D.; BASILE, M. J.; KENNELLY, E. J. Anthocyanin antioxidants from edible fruits. Food Chemistry, Barking, v. 84, n. 1, p. 23-28, 2004.

EVANS, P.; HALLIWELL, B. Micronutrients: Oxidant/antioxidant status. British Journal of Nutrition, Cambridge, v. 85, n. 2 , p. S67-S74, 2001. http://dx.doi.org/10.1079/BJN2000296

FIRUZI, O.; LACANNA, A.; PETRUCCI, R.; MARROSU, G.; SASO, $L$. Evaluation of the antioxidant activity of flavonoids by "ferric reducing antioxidant power" assay and cyclic voltammetry. Biochimica et Biophysica Acta (BBA) - General Subjects, Oxford, v. 1721, n. 1-3, p. 174-184, 2005. PMid:15652192. http:// dx.doi.org/10.1016/j.bbagen.2004.11.001

FRANCISCO, M. L. L. D.; RESURRECCION, A. V. A. Total phenolics and antioxidant capacity of heat-treated peanut skins. Journal of Food Composition and Analysis, Oxford, v. 22 , n. 1, p. 16-24, 2009. http://dx.doi.org/10.1016/j.jfca.2008.05.012 GUIMARÃES, R.; BARROS, L.; BARREIRA, J. C. M.; SOUSA, M. J.; CARVALHO, A. M.; FERREIRA, I. C. F. R. Targeting excessive free radicals with peels and juices of citrus fruits: Grapefruit, lemon, lime and orange. Food and Chemical Toxicology, Philadelphia, v. 48, n. 1, p. 99-106, 2010. PMid:19770018. http:// dx.doi.org/10.1016/j.fct.2009.09.022

HOSSAIN, M. A.; RAHMAN, S. M. M. Total phenolics, flavonoids and antioxidant activity of tropical fruit pineapple. Food Research International, Oxford, v. 44, n. 3, p. 672-676, 2011. http://dx.doi.org/10.1016/j.foodres.2010.11.036

IKRAM, E. H. K.; ENG, K. H.; JALIL, A. M. M.; ISMAIL, A.; IDRIS, S.; AZLAN, A.; NAZRI, H. S. M.; DITON, N. A. M.; MOKHTAR, R. A. M. Antioxidant capacity and total phenolic content of Malaysian underutilized fruits. Journal of Food Composition and Analysis, Oxford, v. 22, n. 5, p. 388-393, 2009. http://dx.doi. org/10.1016/j.jfca.2009.04.001

INSTITUTE OF MEDICINE - IOM. Dietary Reference Intakes for Vitamin A, Vitamin K, Arsenic, Boron, Chromium, Copper, lodine, Iron, Manganese, Molybdenum, Nickel, Silicon, Vanadium, and Zinc. Washington: National Academy Press, 2002. $797 \mathrm{p}$. 
Total antioxidant capacity, total phenolic content and mineral elements in the fruit peel of Myrciaria cauliflora Araújo, C. R. R. et al.

JAYAPRAKASHA, G. K.; NEGI, P. S.; JENA, B. S.; RAO, L. J. M. Antioxidant and antimutagenic activities of Cinnamomum zeylanicum fruit extracts. Journal of Food Composition and Analysis, Oxford, v. 20, n. 3-4, p. 330-336, 2007. http://dx.doi. org/10.1016/j.jfca.2006.07.006

JOSHIPURA, K. J.; HU, F. B.; MANSON, J. E.; STAMPFER, M. J.; RIMM, E. B.; SPEIZER, F. E.; COLDITZ, G.; ASCHERIO, A.; ROSNER, B.; SPIEGELMAN, D.; WILLETT, W. C. The effect of fruit and vegetable intake on risk for coronary heart disease. Annals of Internal Medicine, Philadelphia, v. 134, n. 12, p. 1106-1114, 2001. http://dx.doi.org/10.7326/0003-4819-134$12-200106190-00010$

KONCZAK, I.; ROULLE, P. Nutritional properties of commercially grown native Australian fruits: lipophilic antioxidants and minerals. Food Research International, Oxford, v. 44, n. 7, p. 2339-2344, 2011. http://dx.doi.org/10.1016/j.foodres.2011.02.023

LEITE-LEGATTI, A. V.; BATISTA, A. G.; ROMANELLI, N.; DRAGANO, V.; MARQUES, A. C.; MALTA, L. G.; RICCIO, M. F.; EBERLIN, M. N.; MACHADO, A. R. T.; CARVALHO-SILVA, L. B.; RUIZ, A. L. T. G.; CARVALHO, J. E.; PASTORE, G. M.; JÚNIOR, M. R. M. Jaboticaba peel: Antioxidant compounds, antiproliferative and antimutagenic activities. Food Research International, Oxford, v. 49, n. 1, p. 596-603, 2012. http://dx.doi.org/10.1016/j. foodres.2012.07.044

LETERME, P.; BULdGEN, A.; ESTRAdA, F.; LONDOÑO, A. M. Mineral content of tropical fruits and unconventional foods of the Andes and the rain forest of Colombia. Food Chemistry, Barking, v. 95, n. 4, p. 644-652, 2006.

MACEDO-COSTA, M. R.; DINIZ, D. N.; CARVALHO, C. M.; PEREIRA, M. S. V.; PEREIRA, J. V.; HIGINO, J. S. Effectiveness of the Myrciaria cauliflora (Mart.) O. Berg. extract on oral bacteria. Brazilian Journal of Pharmacognosy, Curitiba, v. 19, n. 4, p. 565-571, 2009.

MORAIS, M. C.; LUQMAN, S.; KONDRATYUK, T. P.; PETRONIO, M. S.; REGASINI, L. O.; SILVA, D. H.; BOLZANI, V. S.; SOARES, C. P.; PEZZUTO, J. M. Suppression of TNF- $\alpha$ induced NFkB activity by gallic acid and its semi-synthetic esters: Possible role in cancer chemoprevention. Natural Product Research, Roma, v. 24, n. 10, p. 1758-1765, 2010. PMid:20408045. http:// dx.doi.org/10.1080/14786410903335232

NACZK, M.; SHAHIDI, F. Phenolics in cereals, fruits and vegetables: occurrence, extraction and analysis. Journal of Pharmaceutical and Biomedical Analysis, Oxford, v. 41, n. 5, p. 1523-1542, 2006. PMid:16753277. http://dx.doi.org/10.1016/j. jpba.2006.04.002

NANDA, V.; SARKAR, B. C.; SHARMA, H. K.; BAWA, A. S. Physico-chemical properties and estimation of mineral content in honey produced from different plants in Northern India. Journal of Food Composition and Analysis, Oxford, v. 16, n. 5, p. 613-619, 2003. http://dx.doi.org/10.1016/S08891575(03)00062-0
NAOZUKA, J.; MARANA, S. R.; OLIVEIRA, P. V. Water-soluble $\mathrm{Cu}, \mathrm{Fe}, \mathrm{Mn}$ and $\mathrm{Zn}$ species in nuts and seeds. Journal of Food Composition and Analysis, Oxford, v. 23, n. 1, p. 78-85, 2010. http://dx.doi.org/10.1016/j.jfca.2009.08.003

PÉREZ-JIMÉNEZ, J.; ARRANZ, S.; TABERNERO, M.; DÍAZRUBIO, M. E.; SERRANO, J.; GOÑI, I.; SAURA-CALIXTO, F. Updated methodology to determine antioxidant capacity in plant foods, oils and beverages: extraction, measurement and expression of results. Food Research International, Oxford, v. 41, n. 3, p. 274-285, 2008. http://dx.doi.org/10.1016/j. foodres.2007.12.004

RAHMAN, I.; ADCOCK, I. M. Oxidative stress and redox regulation of lung inflammation in COPD. European Respiratory Journal, Le Kremlin-Bicêtre, v. 28, n. 1, p. 219-242, 2006.

REYNERTSON, K. A.; WALLACE, A. M.; ADACH, S.; GIL, R. R.; YANG, H.; BASILE, M. J.; D'ARMIENTO, J.; WEINSTEIN, I. B.; KENNELLY, E. J. Bioactive depsides and anthocyanins from jaboticaba (Myrciaria cauliflora). Journal of Natural Product, Columbus, v. 69, n. 8, p. 1228-1230, 2006. PMid:16933884. http://dx.doi.org/10.1021/np0600999

REYNERTSON, K. A.; YANG, H.; JIANG, B.; BASILE, M. J.; KENNELLY, E. J. Quantitative analysis of antiradical phenolic constituents from fourteen edible Myrtaceae fruits. Food Chemistry, Barking, v. 109, n. 4, p. 883-890, 2008.

ROWELL, D. L. Soil Science: Methods and Applications. London: Longman Group, 1994.

RUFINO, M. S. M.; ALVES, R. E.; BRITO, E. S.; PÉREZ-JIMÉNEZ, J.; SAURA-CALIXTO, F.; MANCINI-FILHO, J. Bioactive compounds and antioxidant capacities of 18 non-traditional tropical fruits from Brazil. Food Chemistry, Barking, v. 121, n. 4, p. 996-1002, 2010.

SAHREEN, S.; KHAN, M. R.; KHAN, R. A. Evaluation of antioxidant activities of various solvent extracts of Carissa opaca fruits. Food Chemistry, Barking, v. 122, n. 4, p. 1205-1211, 2010.

SÁNCHEZ-MORENO, C.; LARRAURI, J. A.; SAURA-CALIXTO, F. A procedure to measure the antiradical efficiency of polyphenols. Journal of the Science of Food and Agriculture, Malden, v. 76, n. 2, p. 270-276, 1998. http://dx.doi.org/10.1002/(SICI)10970010(199802)76:2<270::AID-JSFA945>3.0.CO;2-9

SANTOS, D. T.; VEGGI, P. C.; MEIRELES, M. A. A. Extraction of antioxidant compounds from jabuticaba (Myrciaria cauliflora) skins: yield, composition and economical evaluation. Journal of Food Engineering, Davis, v. 101, n. 1, p. 23-31, 2010.

SILVA, T. M.; DIAS, M. D.; PEREIRA, M T.; TAKAHASHI, J. A.; FERRAZ, V P.; PILÓ-VELOSO, D.; ALCÂNTARA, A. F. C. Effect ofthe $\gamma$-radiation on phenol fractions obtained from the leaves of Echinodorus macrophyllus Mich. Radiation Physics and Chemistry, Oxford, v. 81, n. 1, p. 22-26, 2012.

STATSOFT. Statistica ${ }^{\circledR}$. Data analysis software. version 7.0. Tulsa: StatSoft, Inc., 2001. 
Total antioxidant capacity, total phenolic content and mineral elements in the fruit peel of Myrciaria cauliflora Araújo, C. R. R. et al.

SULAIMAN, S. F.; YUSOFF, N. A. M.; ELDEEN, I. M.; SEOW, E. M.; SAJAK, A. A. B.; SUPRIATNO; OOI, K. L. Correlation between total phenolic and mineral contents with antioxidant activity of eight Malaysian bananas (Musa sp). Journal of Food Composition and Analysis, Oxford, v. 24, n. 1, p. 1-10, 2011. http://dx.doi.org/10.1016/j.jfca.2010.04.005

VELIOGLU, Y. S.; MAZZA, G.; GAO, L.; OOMAH, B. D. Antioxidant activity and total phenolics in selected fruits, vegetables, and grain products. Journal of Agriculture and Food Chemistry, Davis, v. 46, n. 10, p. 4113-4117, 1998.

VERMA, A. R.; VIJAYAKUMAR, M.; RAO, C. V.; MATHELA, C. $\mathrm{S}$. In vitro and in vivo antioxidant properties and DNA damage protective activity of green fruit of Ficus glomerata. Food and Chemical Toxicology, Philadelphia, v. 48, n. 2, p. 704-709, 2010. PMid:19951737. http://dx.doi.org/10.1016/j.fct.2009.11.052
YEH, J. Y.; HSIEH, L. H.; WU, K. T.; TSAI, C. F. Antioxidant properties and antioxidant compounds of various extracts from the either basidiomicete Grifola frondosa (Maitake). Molecules, Basel, v. 16, n. X, p. 3197-3211, 2011. PMid:21499220. http:// dx.doi.org/10.3390/molecules 16043197

ZHAO, H.; DONG, J.; LU, J.; CHEN, J.; LI, Y.; SHAN, L.; LIN, Y.; FAN, W.; GU, G. Effects of extraction solvent mixtures on antioxidant activity evaluation and their extraction capacity and selectivity for free phenolic compounds in Barley (Hordeum vulgare L.). Journal of Agriculture and Food Chemistry, Davis, v. 54, n. 19, p. 7277-7286, 2006.

ZIELINSKI, H.; KOZLOWSKA, H. Antioxidant activity and total phenolics in selected cereal grains and their different morphological fractions. Journal of Agriculture and Food Chemistry, Davis, v. 48, n. 6, p. 2008-2016, 2000. 